\title{
Effect of Intercropping Systems on Economics and Yield of Pigeonpea (Cajanus cajan L.), Pearlmillet (Pennisetum glaucum L.) and Greengram (Vigna radiata L.) under Western Haryana Condition
}

\author{
Niranjan Kumar Barod*, Satish Kumar and A.K. Dhakaand Mohammad Irfan \\ Department of Agronomy, CCS HAU Hisar, India \\ *Corresponding author
}

\begin{tabular}{|c|c|}
\hline & A B S T R A C T \\
\hline & \multirow{7}{*}{$\begin{array}{l}\text { The investigation entitled "Response of nitrogen application in wheat succeeding } \\
\text { pigeonpea intercropped with pearlmillet and greengram" was carried out at the research } \\
\text { farm of Chaudhary Charan Singh Haryana Agricultural University, Hisar during kharif and } \\
\text { rabi season } 2011-12 \text { and } 2012-13 \text {. It comprised of } 12 \text { treatments and it was replicated } \\
\text { thrice in randomized block design. Based on aforesaid investigation it was found that } \\
\text { intercropping systems influenced the grain, straw and biological yield were significantly } \\
\text { highest in sole crop i.e. pigeonpea ( } 1983 \text { and } 2059,2059 \text { and } 5947 \text { and } 7777 \text { and } 8006 \\
\mathrm{~kg} / \mathrm{ha} \text { ) respectively, pearlmillet }(2122 \text { and } 2218,5999 \text { and } 6200 \text { and } 8121 \text { and } 8418 \mathrm{~kg} / \mathrm{ha}) \\
\text { respectively and greengram ( } 1319 \text { and } 1402,3925 \text { and } 4175 \text { and } 5244 \text { and } 5576 \mathrm{~kg} / \mathrm{ha} \text { ) } \\
\text { respectively during } 2011 \text { and } 2012 \text { crop seasons. Among all the treatments maximum gross } \\
\text { return, net returns and B C ratio was recorded when pigeonpea was planted at } 75 \mathrm{~cm} \text { row } \\
\text { spacing intercropped with two rows of greengram and closely followed by pigeonpea } 75 \\
\text { cm + greengram (1:1). Minimum net returns and B C ratio was recorded in pearlmillet } \\
\text { sole. }\end{array}$} \\
\hline & \\
\hline & \\
\hline $\begin{array}{l}\text { Greengram, } \\
\text { Intercropping } \\
\text { systems. }\end{array}$ & \\
\hline Article Info & \\
\hline $\begin{array}{l}\text { Accepted: } \\
\text { 24 February } 2017 \\
\text { Available Online: } \\
10 \text { March } 2017\end{array}$ & \\
\hline & \\
\hline
\end{tabular}

\section{Introduction}

Pigeonpea (Cajanuscajan L.) also known as arhar, tur or red gram is one of the most important kharif pulse crop cultivated in India. It is next to only chickpea in area and production among all the pulse crop grown in India. Pigeonpea grown as a sole crop is not economically viable because of its slow initial growth rate, low productivity and longer duration. Because of slow growth the crops face a lot of competition with weeds and the inter-row space was not utilized properly (Velaytham et al., 2003). In order to have better utilization of the resources, growing a short duration intercrop like greengram and pearlmillet between the pigeonpea rows helps in utilization of available resources without affecting its productivity. Short duration and short statured crops like pearlmillets and greengram and would prove to be a viable intercropping system. Intercropping with short duration pulses like greengram and cereals like pear millet in pigeonpea enhance total productivity (Sharma et al., 1995). Greengram (Vignaradiata L.) is also an important kharif pulse crop of India. It is an excellent source of high quality protein. As short duration crop it fit well in various multiple and intercropping systems (Pujari and Sheelvantar, 2002). Pearlmillet (Pennisetum glaucum L.) is one of the most 
important rain fed crop of India. Its grains possess higher protein content with higher level of essential amino acids. The inclusion of pearlmillet with pigeonpea will definitely ensure the fulfilment of dietary requirement and enhanced productivity of crops per unit area per unit time (Anonymous, 2004).

Intercropping is an age-old practice being followed by subsistence farmers to achieve their domestic needs. The main advantage of the intercropping is that the component crops are able to use the growth resources more efficiently (Willey, 1979). Nitrogen needs of cereals intercropped with legumes are reported to be less than for sole cropping due to transfer of some of the fixed nitrogen by legumes to the associated cereals during the growing season (Willey, 1979).

Intercropping of legumes with pearlmillet has been reported to be more stable and dependable than sole cropping (Patel et al., 1998). In intercropping systems, selection of compatible crops with different growth pattern and their suitable planting geometries are very important because, it helps to minimize inter and intra specific competitions for resources. A lot of work has been done on nutrient management in pigeonpea and wheat crop alone. However, very less information is available on the effect of pearlmillet, greengram intercropping in pigeonpea. Therefore, in view of the above, the present investigation was planted.

\section{Materials and Methods}

The experiment was conducted at the Agronomy Research Farm, CCS Haryana Agricultural University, Hisar during 2011 and 2012. It is situated at $29^{\circ} 10^{\prime} \mathrm{N}$ latitude, $75^{\circ} 46^{\prime} \mathrm{E}$ longitude and at an altitude of 215.2 meters above mean sea level, the experiment was laid out in randomized block design in Kharif. The kharif crops pigeon was as sole and in combination with pearlmillet and greengram at different spacing and rows in the kharif season during 2011 and 2012 resulting in 12 treatments. In the pigeonpea (Manak), pearlmillet (HHB-67 Improved) and greengram (Basanti) was sown on $17^{\text {th }}$ June during the year 2011 and $18^{\text {th }}$ June during the year 2012.

The soil of the experimental unit was sandy loam and the soil $\mathrm{pH}$ was 7.8 and 7.9, while the EC was 0.39 and $0.40 \mathrm{dSm}^{-1}$ during 2011 and 2012, respectively. The organic carbon of the soil was 0.41 and 0.40 per cent during both the years of study. The soils of the experiential field was sandy loam in texture, poor organic matter $(0.41)$ and low in available nitrogen $(162 \mathrm{~kg} / \mathrm{ha})$, medium in available phosphorus (25 kg/ha) and high in available potassium (305 kg/ha) and slightly alkaline in reaction.

\section{Results and Discussion}

\section{Yield of pigeonpea}

The effect of intercropping systems under different spacing influenced the pigeonpea grain yield (Table 1). The widening of row spacing reduced the grain yield of the pigeonpea. The higher yield at lesser spacing of $45 \mathrm{~cm}$ was the result of more number of plants per unit area. Grain yield per hectare is function of number of plants, pods per plant, and number of grains per pod and grain yield per plant. Under different intercropping systems the higher grain yield of pigeonpea was recorded from pigeonpea $(75 \mathrm{~cm})+$ greengram (1:2) systems however; it was at par with the intercropping systems pigeonpea $(75 \mathrm{~cm})+$ greengram $(1: 1)$.

It might be due to synergistic effect of component crop. Similar result was obtained by Kumar et al., 2005; Rathod et al., 2004 and Kumar et al., 2012. 
Table.1 Effect of intercropping systems on yield of pigeonpea

\begin{tabular}{|c|c|c|c|c|c|c|c|c|c|}
\hline \multirow{3}{*}{ Treatment } & \multicolumn{9}{|c|}{ Yield $\left(\mathrm{kgha}^{-\mathbf{1}}\right)$} \\
\hline & \multicolumn{3}{|c|}{ Grain yield } & \multicolumn{3}{|c|}{ Straw yield } & \multicolumn{3}{|c|}{ Biological yield } \\
\hline & 2011 & 2012 & Pooled & 2011 & 2012 & $\begin{array}{c}\text { Poole } \\
\text { d }\end{array}$ & 2011 & 2012 & Pooled \\
\hline Pigeonpea sole $(45 \mathrm{~cm})$ & 1832 & 1911 & 1871 & 5373 & 5488 & 5430 & 7105 & 7399 & 7252 \\
\hline Pigeonpea - Paired row $(30: 60 \mathrm{~cm})$ & 1983 & 2059 & 2021 & 5794 & 5947 & 5870 & 7777 & 8006 & 7891 \\
\hline $\begin{array}{c}\text { Pigeonpea }(75 \mathrm{~cm})+\text { Pearlmillet } \\
(1: 1)\end{array}$ & 1415 & 1593 & 1504 & 4496 & 4711 & 4603 & 5911 & 6304 & 6107 \\
\hline $\begin{array}{c}\text { Pigeonpea }(75 \mathrm{~cm})+\text { Pearlmillet } \\
(1: 2)\end{array}$ & 1384 & 1563 & 1473 & 4449 & 4550 & 4499 & 5833 & 6113 & 5973 \\
\hline $\begin{array}{c}\text { Pigeonpea }(75 \mathrm{~cm})+\text { Greengram } \\
(1: 1)\end{array}$ & 1530 & 1600 & 1565 & 4416 & 4571 & 4493 & 5946 & 6171 & 6058 \\
\hline $\begin{array}{c}\text { Pigeonpea }(75 \mathrm{~cm})+\text { Greengram } \\
(1: 2)\end{array}$ & 1611 & 1684 & 1647 & 4625 & 4826 & 4725 & 6236 & 6510 & 6373 \\
\hline $\begin{array}{c}\text { Pigeonpea }(90 \mathrm{~cm})+\text { Pearlmillet } \\
(1: 1)\end{array}$ & 1329 & 1473 & 1401 & 4131 & 4280 & 4205 & 5460 & 5753 & 5606 \\
\hline $\begin{array}{c}\text { Pigeonpea }(90 \mathrm{~cm})+\text { Pearlmillet } \\
(1: 2)\end{array}$ & 1296 & 1406 & 1351 & 3959 & 4095 & 4027 & 5255 & 5501 & 5378 \\
\hline $\begin{array}{c}\text { Pigeonpea }(90 \mathrm{~cm})+\text { Greengram } \\
(1: 1)\end{array}$ & 1332 & 1503 & 1417 & 4236 & 4335 & 4285 & 5568 & 5838 & 5703 \\
\hline $\begin{array}{c}\text { Pigeonpea }(90 \mathrm{~cm})+\text { Greengram } \\
(1: 2)\end{array}$ & 1369 & 1540 & 1454 & 4523 & 4458 & 4490 & 5892 & 5998 & 5945 \\
\hline SEm \pm & 73 & 66 & 69 & 92 & 102 & 97 & 107 & 126 & 116 \\
\hline $\mathrm{CD}$ at $5 \%$ & 222 & 197 & 209 & 268 & 293 & 280 & 312 & 364 & 338 \\
\hline
\end{tabular}


Table.2 Effect of intercropping systems on yield of pearlmillet

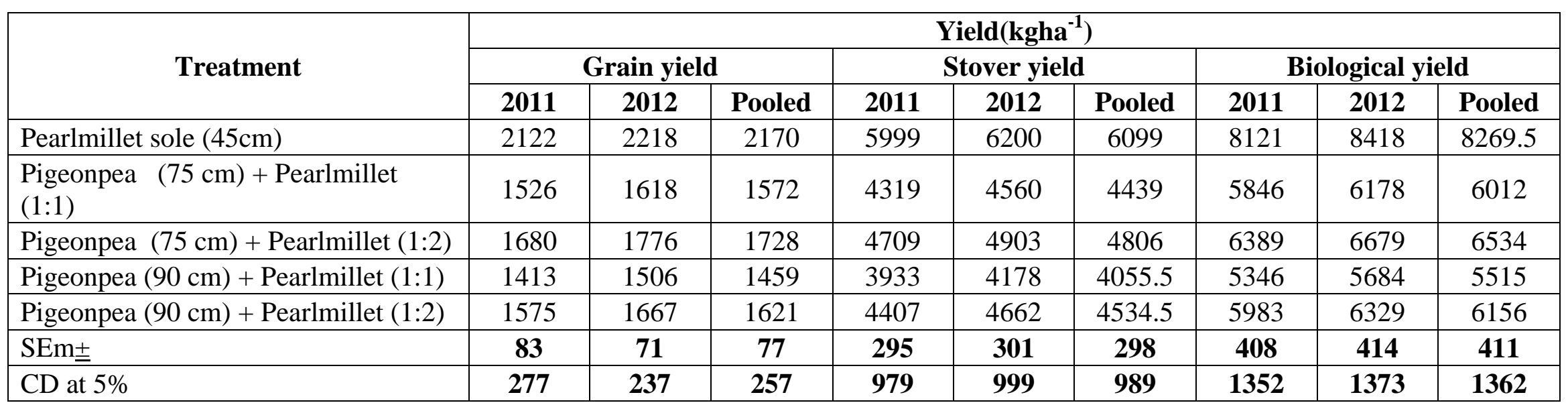

Table.3 Effect of intercropping systems on yield of greengram

\begin{tabular}{|c|c|c|c|c|c|c|c|c|c|}
\hline \multirow{3}{*}{ Treatment } & \multicolumn{9}{|c|}{ Greengram } \\
\hline & \multicolumn{3}{|c|}{ Grain yield $\left(\mathrm{kgha}^{-1}\right)$} & \multicolumn{3}{|c|}{ Stover yield $\left(\mathrm{kgha}^{-1}\right)$} & \multicolumn{3}{|c|}{ Biological yield $\left(\mathrm{kgha}^{-1}\right)$} \\
\hline & 2011 & 2012 & Pooled & 2011 & 2012 & Pooled & 2011 & 2012 & Pooled \\
\hline Greengram sole $(30 \mathrm{~cm})$ & 1319 & 1402 & 1361 & 3925 & 4175 & 4050 & 5244 & 5576 & 5410 \\
\hline $\begin{array}{l}\text { Pigeonpea }(75 \mathrm{~cm})+\text { Greengram } \\
(1: 1)\end{array}$ & 692 & 789 & 741 & 2192 & 2502 & 2347 & 2884 & 3291 & 3088 \\
\hline $\begin{array}{l}\text { Pigeonpea }(75 \mathrm{~cm})+\text { Greengram } \\
(1: 2)\end{array}$ & 853 & 946 & 900 & 2668 & 2957 & 2813 & 3520 & 3903 & 3712 \\
\hline $\begin{array}{l}\text { Pigeonpea }(90 \mathrm{~cm})+\text { Greengram } \\
(1: 1)\end{array}$ & 622 & 714 & 668 & 1973 & 2264 & 2119 & 2594 & 2977 & 2786 \\
\hline $\begin{array}{l}\text { Pigeonpea }(90 \mathrm{~cm})+\text { Greengram } \\
(1: 2)\end{array}$ & 774 & 867 & 821 & 2281 & 2560 & 2421 & 3055 & 3427 & 3241 \\
\hline $\mathrm{SEm} \pm$ & 51 & 47 & 49 & 68 & 64 & 66 & 56 & 121 & 89 \\
\hline $\mathrm{CD}$ at $5 \%$ & 147 & 139 & 143 & 201 & 189 & 195 & 166 & 357 & 262 \\
\hline
\end{tabular}


Table.4 Effect of intercropping systems on economics

\begin{tabular}{|c|c|c|c|c|c|c|c|c|c|c|}
\hline \multirow[b]{2}{*}{ Treatment } & \multirow{2}{*}{$\begin{array}{c}\text { Total } \\
\text { Cost } \\
\left(\text { Rs.ha }^{-1}\right)\end{array}$} & \multicolumn{3}{|c|}{ Gross returns $\left(\right.$ Rs.ha $\left.^{-1}\right)$} & \multicolumn{3}{|c|}{ Net returns $\left(\right.$ Rs.ha $\left.^{-1}\right)$} & \multicolumn{3}{|c|}{ B C Ratio } \\
\hline & & 2011 & 2012 & Pooled & 2011 & 2012 & Pooled & 2011 & 2012 & Pooled \\
\hline Pigeon pea sole $(45 \mathrm{~cm})$ & 93285 & 136920 & 137972 & 137446 & 43635 & 44687 & 44161 & 1.47 & 1.48 & 1.47 \\
\hline Pearlmillet sole $(45 \mathrm{~cm})$ & 92843 & 92162 & 95710 & 93936 & 681 & 868 & 775 & 0.99 & 1.03 & 1.01 \\
\hline Greengram sole $(30 \mathrm{~cm})$ & 93840 & 146517 & 126508 & 136513 & 52677 & 32668 & 42673 & 1.56 & 1.35 & 1.45 \\
\hline Pigeon pea - Paired row $(30: 60 \mathrm{~cm})$ & 93285 & 141039 & 142349 & 141694 & 47754 & 49064 & 48409 & 1.51 & 1.53 & 1.52 \\
\hline Pigeon pea $(75 \mathrm{~cm})+$ Pearlmillet $(1: 1)$ & 94887 & 135130 & 142729 & 138930 & 40243 & 47842 & 44043 & 1.42 & 1.50 & 1.46 \\
\hline Pigeon pea $(75 \mathrm{~cm})+$ Pearlmillet $(1: 2)$ & 96078 & 135281 & 143093 & 139187 & 39203 & 47015 & 43109 & 1.41 & 1.49 & 1.45 \\
\hline Pigeon pea $(75 \mathrm{~cm})+$ Greengram $(1: 1)$ & 93918 & 152018 & 158065 & 155042 & 58100 & 64147 & 61124 & 1.62 & 1.68 & 1.65 \\
\hline Pigeon pea $(75 \mathrm{~cm})+$ Greengram $(1: 2)$ & 94140 & 161672 & 167004 & 164338 & 67532 & 72864 & 70198 & 1.72 & 1.77 & 1.74 \\
\hline Pigeon pea $(90 \mathrm{~cm})+$ Pearlmillet $(1: 1)$ & 94572 & 131690 & 137935 & 134813 & 37118 & 43363 & 40241 & 1.39 & 1.46 & 1.42 \\
\hline Pigeon pea $(90 \mathrm{~cm})+$ Pearlmillet $(1: 2)$ & 95565 & 131827 & 137208 & 134518 & 36262 & 41643 & 38953 & 1.38 & 1.44 & 1.41 \\
\hline Pigeon pea $(90 \mathrm{~cm})+$ Greengram $(1: 1)$ & 93672 & 141071 & 151476 & 146274 & 47309 & 57714 & 52512 & 1.50 & 1.62 & 1.56 \\
\hline Pigeon pea $(90 \mathrm{~cm})+$ Greengram $(1: 2)$ & 93945 & 148468 & 158704 & 153586 & 54523 & 64759 & 59641 & 1.58 & 1.69 & 1.63 \\
\hline
\end{tabular}


Irrespective of row spacing and row ratio the grain yield of pigeonpea was recorded higher in greengram intercrop, whereas, it was lesser when pearlmillet was taken as intercrop which might be due to the fact that in pigeonpea + greengram inter crop being both the crop as legume, these may not be competition for nitrogen which might be when pearlmillet was taken as intercrop and which reduced the yield attributes and ultimately lower pigeonpea yield when pearlmillet was intercrop.

The various intercropping systems and sole cropping systems had significantly effect on straw yield of pigeonpea crop. Straw yield was found higher in sole crop as compared to intercropping systems. In pigeonpea intercropping, it decreased which was due to lower plant population as compared to sole crop. Straw yield of pigeonpea in 1: 1 systems irrespective of spacing was found higher as compared to 1: 2 systems, except $75 \mathrm{~cm}$ spacing, which might be due to less competition among plant of main crop. Significantly, higher biological yield of pigeonpea was recorded with pigeonpea sole $(45 \mathrm{~cm})$ this is due to more grain and straw yield obtained from pigeonpea sole $(45 \mathrm{~cm})$. Kumar et al., 2005 and Rathod et al., (2004) also reported similar result.

\section{Yield of pearlmillet}

Pearlmillet sole crop produced significantly higher grain, straw and biological yield as compared to different intercropping systems. It was 26.31 and 34.73 per cent higher as compared to pigeonpea $(75 \mathrm{~cm})+$ pearlmillet $(1: 2)$ and pigeonpea $(90 \mathrm{~cm})+$ pearlmillet $(1: 2)$. Irrespective of pigeonpea row spacing, two rows of intercrop produced higher grain, straw and biological yield as compared to single row though the difference were no significant among them during both crop year (Table 2). The grain and straw yield was recorded to be significantly higher in sole system over intercropping systems, which might be due to higher plant population of pearlmillet in sole crop as compared to intercropping systems. Lower yield of pearlmillet was recorded from other intercropping treatments because of less number of plants per hectare these results are accordance with Choudhary and Gautam, (2006) and Kuri et al., (2012).

\section{Yield of greengram}

The intercropping systems influenced the greengram grain; straw and biological yield (Table 3). In case of greengram the grain, straw and biological yield was recorded maximum in sole crop, which was due to more number of plants and better yield attributes of the crop in one side and better interception of sunlight and more photosynthesis resulting into more production of photosynthates and translocation to the economic part on the other side Kumar et al., (2005), and Sharma et al., (2010) also reported similar result. The higher yield of greengram in pigeonpea $(75 \mathrm{~cm})+$ greengram (1:2) systems was because of more number of rows of greengram and reduced competition between and within crop plants due to more availability of space (Bishnoi et al., 1987). In intercropping treatments, there was decrease in intercrop yield as compared to sole crop, which might be due to less number of plants per unit area and the reduction in photosynthetic activity of plant because of shading effect of main crop resulting in less accumulation of photosynthates and its diversion to reproductive parts, similar result was recorded by Kumar et al., (2005).

\section{Economics}

Maximum cost was increased when two rows of pearlmillet was intercropped with pigeonpea at $75 \mathrm{~cm}$, whereas, minimum was 
increased in sole pearlmillet. Although sole cropping of greengram was expensive as compared to pigeonpea either as normal sowing or in paired row but still less cost was incurred in treatments involving intercropping of greengram with pigeonpea as compared to intercropping of pearlmillet with pigeonpea. Maximum gross returns of Rs. 1,61,672 and Rs. 1,67,004 were recorded in year 2011 and 2012, respectively, in pigeonpea $(75 \mathrm{~cm})+$ greengram (1:2) treatment, whereas minimum gross returns was recorded in sole pearlmillet (Table 4.). Minimum net return (Rs. 681 and 868) were recorded in sole pearlmillet, whereas, greengram intercropping with pigeonpea in $1: 2$ ratio at $75 \mathrm{~cm}$ row spacing resulted in maximum net return (Rs. 67,532 and Rs. 72,864) during 2011 and 2012, respectively. Sole cropping of greengram was superior in terms of net returns (Rs. 52,677) as compare to normal sowing (Rs. 43,635 ) or paired row sowing (Rs. 47,754) of pigeon ea during first year (2011) of study but this trend was reversed during second year i.e.2012. Maximum (1.72 and 1.77) and minimum (0.97 and 1.03) returns per rupee invested, was estimated in two row intercropping of greengram with pigeonpea at $75 \mathrm{~cm}$ and sole pearlmillet, respectively, during 2011 and 2012 (Kantwa et al., 2005). This might be due to marginal difference in yield of pigeonpea and additional yield of green gram, which resulted in higher net return in pigeonpea + greengram cropping system than in sole pigeonpea. Kumar et al., 2003 and Sharma et al., 2012 also reported similar results.

\section{References}

Anonymous. 2004. Sustaining nutritional security. In: Survey of Indian Agriculture, pp. 37-38.

Bishnoi, K.C., Singh, B. and Singh, A. 1987. Studies on compatibility of greengram and blackgram cultivars in pigeonpea based intercropping systems. Indian J.
Agron., 32: 127-129.

Choudhary, R.S. and Gautam, R.C. 2006. Influence of cropping systems and nutrient management on nutrient uptake, protein content, yield, productivity and net returns of pearlmillet (Pennisetumglaucum). Annals of Agric. Res. New Series, 27(4): 302-305.

Kantwa, S.R., Ahlawat, I.P.S. and Gangaiah, B. 2005. Effect of land configuration, post-monsoon irrigation and phosphorus on performance of sole and intercropped pigeonpea (Cajanuscajan L.). Indian J. Agron., 50(4): 278-280.

Kumar, P., Rana, K.S. and Rana, D.S. 2012. Effect of planting systems and phosphorus with bio-fertilizers on the performance of sole and intercropped pigeonpea (Cajanuscajan L.) under rainfed conditions. Indian J. Agron. 57(2): 127-132.

Kumar, S., Singh, R.C. and Kadian, V.S. 2005. Compatibility of pigeonpea and greengram intercropping systems in relation to row ratio and row spacing. Legume Res., 28(3): 213-215.

Kumar, S., Singh, R.C. and Kadian, V.S. 2003. Production potential of pigeonpea (Cajanuscajan L.) and greengram (Vignaradiata) intercropping patterns in semi-arid tract of Haryana. Indian $J$. Agron., 48(4): 259-262.

Kuri, B.R., Yadav, R.S. and Kumawat, A. 2012. Evaluation of pearlmillet (Pennisetumglaucum) and mothbean (Vigna acconitifolia) intercropping systems in hyper-arid partially irrigated north-western plain zones. Indian $J$. Agric. Sci., 82(11): 993-996.

Patel, M.R., Kalyanasundaram, N.K., Patel, I.S., Patel, J.M., Patel, S.I., Patel, B.M. andPatil, R.G. 1998. Effect of additive and replacement series in intercropping system with pearlmillet. Annals of Arid Zone., 37: 69-74. 
Pujari, B.T. and sheelvantar, M.N. 2002. Dry matter accumulation in plant parts of greengram (Vignaradiata) as influenced by cropping system, row proportion and greengram population levels. Indian $J$. Agric. Res., 36: 156-161.

Rathod, P.S., Halikatti, S.I., Hiremath S.M. and Kajjidoni, S.T. 2004. Influence of different intercrops and row proportions on yield and yield parameters of pigeonpea in vertisols of Dharwad. Karnataka J. Agric. Sci., 17(4): 652-657

Sharma, A., Pandit. S.R., Dharmaraj, P.S. and Chavan, M.2012. Response of Pigeonpea to bio-fertilizers in pigeonpea based intercropping systems under rainfed conditions. Karnataka J. Agric. Sci., 25(3): 322-325.
Sharma, A., Rathod, P.S. and. Basavaraj, K. 2010. Agronomic management of pigeonpea

(Cajanus cajana) based intercropping systems for improving productivity under rainfed conditions. Karnataka J. Agric. Sci., 23(4): 570-574.

Sharma, N.N., Sharma, D. and Paul, S.R. 1995. Intercropping of greengram (Vignaradiata), blackgram (Vignamungo) and sesamum (Sesamumindicum) and pigeonpea (Cajanuscajan L.) under different seeding methods. Indian J. Agron., 40: 386-387.

Willey, R.W. 1979. Intercropping, importance and research need competition and yield advantages. Field Crops, 32(1): 1-10.

\section{How to cite this article:}

Niranjan Kumar Barod, Satish Kumar and A.K. Dhakaand Mohammad Irfan. 2017. Effect of Intercropping Systems on Economics and Yield of Pigeonpea (Cajanus cajan L.), Pearlmillet (Pennisetum glaucum L.) and Greengram (Vigna radiata L.) under Western Haryana Condition. Int.J.Curr.Microbiol.App.Sci. 6(3): 2240-2247. doi: http://doi.org/10.20546/ijcmas.2017.603.256 